\title{
DEMONSTRATION OF BASOPHILIC STIPPLING IN ERYTHROCYTES
}

\author{
BY \\ GEORGE DISCOMBE \\ From the Central Middlesex Hospital, London
}

(RECEIVED FOR PUBLICATION JULY 2, 1953)

The recognition of basophilic stippling in erythrocytes depends largely on subjective factors such as visual acuity and experience. An expert may observe stippling in the ordinary blood film stained with B.D.H. Leishman stain diluted with water at $p \mathrm{H} 6.8$ to 7.0 when less expert observers may see nothing.

If one could increase contrast between the stippling and its background it would become easier to recognize. This increase in contrast can be achieved by dark-ground illumination. A stained particle under dark-ground illumination reflects that light which would be absorbed were it to pass through the stain ; it therefore appears to emit light of a colour complementary to that which it possesses by transmitted light. The thionins and thionols which constitute the basic components of all Romanowsky stains in their blue form absorb orange light, so that particles stained with them appear orange under dark-ground illumination. The red cell, if properly stained, has a pale, yellowish-green outline, within which may occur the orange-coloured dots of light which represent basophilic stippling: these particles are easily differentiated from other particles and debris.

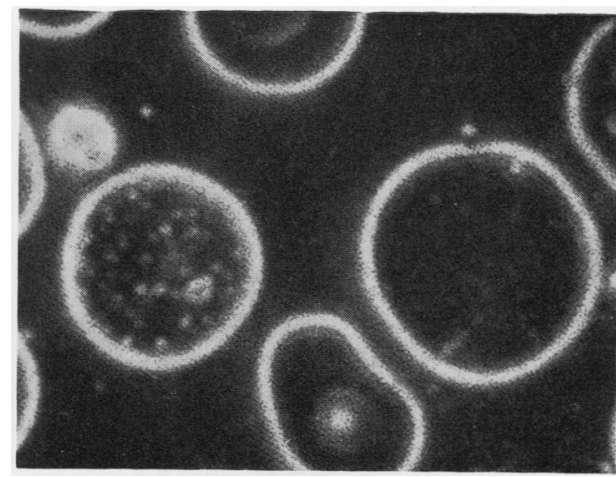

FIG. 1.-Coarse stippling in one, fine stippling in a second cell, $\times 2,700$.
These observations are not original. Saar (1909) appears to have been the first to demonstrate darkground illumination of punctate basophilia in stained films, while Dietrich (1910) repeated his work and claimed that intra-erythrocytic objects corresponding to punctate basophilia could be seen in wet preparations. Ferrata and Boselli (1910) showed that, whereas the substantia reticulo filamentosa could be demonstrated only by supravital staining with brilliant cresyl blue, punctate basophilia could be demonstrated either by supravital staining or by staining a dry fixed film with methylene blue. Naegeli (1923 and 1931) states that he demonstrated punctate "basophilia" in fresh wet, stained, and unstained dry preparations by using dark-ground illumination.

Dark-ground illumination seems never to have been used for routine surveys of blood films for punctate basophilia. In my hands it is much the most certain and reliable technique, while if care is exercised in the selection of microscopic equipment it is no more troublesome than examination by transmitted light.

The film, rather heavily stained as indicated above, is examined with the optical system : focusing dark-ground illuminator, objective $1 / 7$ in. fluorite N.A. 0.95 , eyepiece $\times 15$ straight, $\times 10$ for inclined body tube. Illumination is with a 40 watt high-intensity filament lamp with lamp condenser throwing a slightly convergent beam. (All equipment used was by Cooke, Troughton, and Simms.) Photographs were on Kodak O 250 plates, exposure four minutes, image distance 10 in. from eyepiece, development three minutes in Kodak D 163.

REFERENCES .

Dietrich, A. (1910). Folia haematol., Lpz., 9, 297.

Ferrata, A., and Boselli, S. (1910). Autoriassunti 1910, 8, No. 5. Abstracted Folia. haematol., Lpz., 11 (Referate) 76.

Naegeli, O. (1923). Blutkrankheiten und Blutdiagnostik, 4th ed. Springer, Berlin.

(1931). Ibid., 5th ed.

Saar (1909). Cited by Dietrich (1910). 